\title{
SOUND, NOISE AND SPEECH AT THE 9000-SEAT HOLY TRINITY CHURCH IN FATIMA, PORTUGAL
}

\section{António P.O. CARVALHO, Pedro M.A. SILVA}

University of Porto, Faculty of Engineering, Laboratory of Acoustics

Portugal

carvalho@fe.up.pt

\begin{abstract}
This paper presents the interior acoustical characterization of the 9,000-seat church of the Holy Trinity in the Sanctuary of Fátima, Portugal, inaugurated in 2007. In situ measurements were held regarding interior sound pressure levels (with and without the HVAC equipment working), NC curves, RASTI (with and without the installed sound system) and reverberation time. The results are presented and commented according to the design values. A comparison is made with other churches in the world also with a very large volume (for instance the Basilica Mariacka in Gdańsk). The measured data are also used to calculate a global index of this church acoustic quality using Engel and Kosala's Index Method.
\end{abstract}

\section{INTRODUCTION}

The Catholic church of the Holy Trinity, inaugurated in 2007 in the Sanctuary of Fátima, was pioneer in Portugal because it is the largest church in the country (in number of seats) and deserved a profound and previous acoustic study [1]. The goal of this work is the characterization of its interior acoustics through objective parameters and to check the fulfillment of the acoustic goals previously stated by the owner. In situ measurements were done regarding several objective acoustic parameters (HVAC background sound levels, Noise Criteria - NC, Rapid Speech Transmission Index - RASTI and Reverberation Time - RT). 


\section{THE HOLY TRINITY CHURCH}

Since May 13, 1917 when Virgin Mary appeared to three children shepherds, Fátima $(120 \mathrm{~km}$ northeast from Lisbon) became a world-wide known center of peregrination with the cult of Our Lady of Fátima. In 1919 the construction of a small chapel on Her place of appearance was initiated. A basilica was built in 1953 where the mortal remains of the three little shepherds rest. Soon, even this large basilica started to be insufficient to receive the thousands of pilgrims (Fig. 1). In 2007 the Holy Trinity church was inaugurated (Fig. 2 and 3).
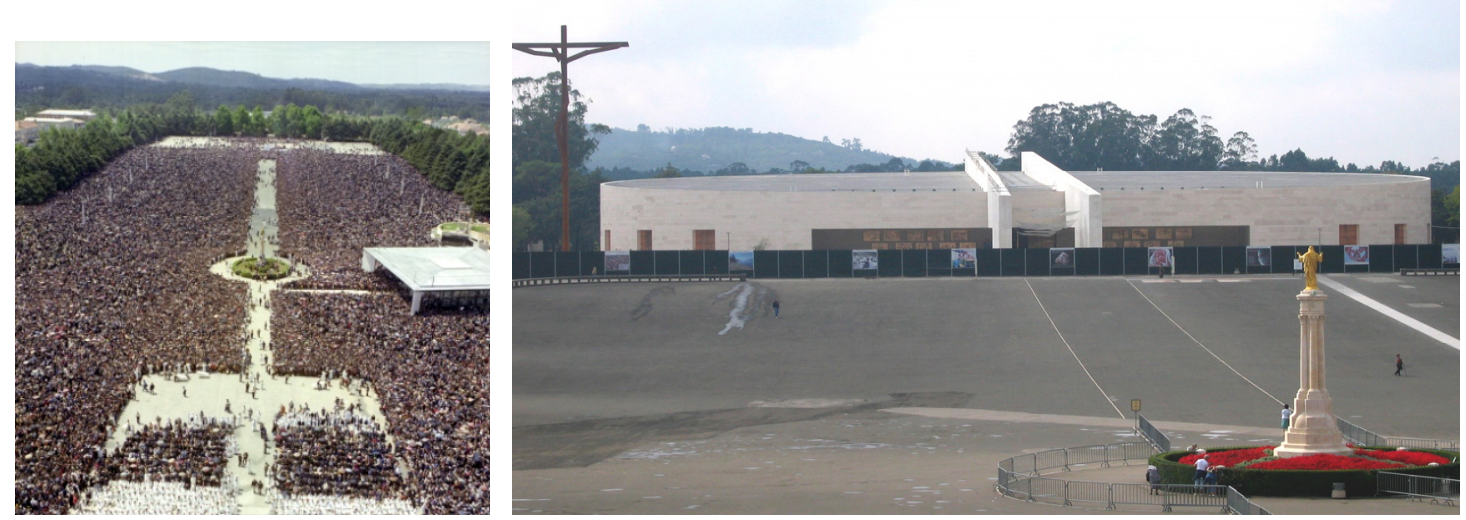

Figures 1 and 2 - Typical May $13^{\text {th }}$ peregrination (left) and the new Holy Trinity church (right)

The church of the Holy Trinity is at the Southwestern top of the Sanctuary of Fátima (blank spot at the top of figure 1). This mega-church (with a seated capacity of about 9,000 people) was designed by the Greek architect Alexandros Tombazis with a $125 \mathrm{~m}$ diameter circular form. Its main dimensions are:

Volume - 130,000 $\mathrm{m}^{3}$

Area $-8,700 \mathrm{~m}^{2}$

Average height $-15 \mathrm{~m}$
Minimum height - $9 \mathrm{~m}$

Maximum height - $20 \mathrm{~m}$

Maximum length - $95 \mathrm{~m}$
Average length - $85 \mathrm{~m}$

Maximum width - $115 \mathrm{~m}$

Average width - $105 \mathrm{~m}$

The main goal for the acoustics of this church was to guaranty very good speech intelligibility without compromising the quality of a good environment for music. As such, the owner established several acoustic goals to be fulfilled in the design phase (Table 1) [1]. Those limits reflect the concern in privileging speech intelligibility without relinquishing a musical minimum comfort and keeping a propitious environment to the meditation and individual prayer. 


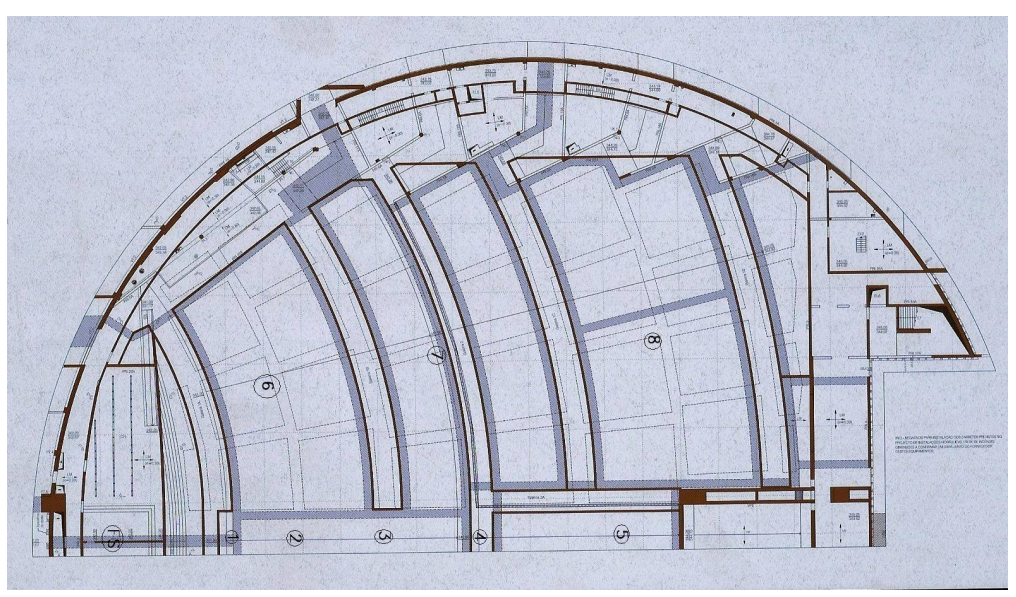

Figure 3 - Holy Trinity church floor half plan with RASTI measuring positions (altar at bottom left).

Table 1 - Limit conditions for the acoustical requirements set by the Owner. [1]

\begin{tabular}{|c|c|c|}
\hline PARAMETERS & $\begin{array}{c}\text { OBJECTIVES OF } \\
\text { PROJECT } \\
\text { [Ideal goals] } \\
\end{array}$ & $\begin{array}{l}\text { ACCEPTABLE } \\
\text { LIMIT } \\
\text { CONDITIONS } \\
\end{array}$ \\
\hline $\begin{array}{l}R T 100 \% \text { occupied }(500-1 \mathrm{k} \mathrm{Hz}) \\
100 \% \text { occupied }(250 \mathrm{~Hz})\end{array}$ & $\begin{array}{l}\leq 1.6 \mathrm{~s} \\
\leq 2.4 \mathrm{~s}\end{array}$ & $\begin{array}{l}\leq 2.0 \mathrm{~s} \\
\leq 2.8 \mathrm{~s}\end{array}$ \\
\hline $\begin{array}{ll}R T & \text { unoccupied }(500-1 \mathrm{k} \mathrm{Hz}) \\
& \text { unoccupied }(250 \mathrm{~Hz}) \\
\end{array}$ & $\begin{array}{l}\leq 2.1 \mathrm{~s} \\
\leq 2.8 \mathrm{~s}\end{array}$ & $\begin{array}{l}\leq 2.6 \mathrm{~s} \\
\leq 3.4 \mathrm{~s}\end{array}$ \\
\hline$N C$ & $\leq 25 \mathrm{~dB}$ & $\leq 30 \mathrm{~dB}^{1}$ \\
\hline$R_{A S T I^{2}}$ & $\geq 0.50$ & $\geq 0.45^{1}$ \\
\hline $\begin{array}{l}\Delta L \text { mean spectral }(45-11,200 \mathrm{~Hz})^{2} \\
\text { (between any two seats in the congregation area) }\end{array}$ & $\leq 4 \mathrm{~dB}$ & $\leq 6 \mathrm{~dB}$ \\
\hline $\begin{array}{l}\Delta L \text { maximum at } 1 / 3 \text { octave band }(141-5,620 \mathrm{~Hz})^{2} \\
\text { (between any two seats in the congregation area) }\end{array}$ & $\leq 6 \mathrm{~dB}$ & $\leq 8 \mathrm{~dB}$ \\
\hline
\end{tabular}

1 - at least on $95 \%$ of the seats; 2 - with Sound Reinforcement System (SRS)

In a church of this dimension (Fig. 7) and with the chosen coverings (for instance the marble on the floor), an acoustic disaster could be foreseen. However, strong measures were taken to oppose the unfavorable designed architectural characteristics of the church and to provide the space with the acoustic comfort demanded by the Owner. A very short list of some of these measures is presented:

- Pews in wood with acoustically tested soft cushions (fig. 4);

- Interior faces of the twelve entrance doors with a perforated wooden finishing (grouped resonators) (fig. 5);

- Choir rear wall and rear assembly wall with diffusers (fig. 6 and 8);

- Presbytery wall with a slight inclination;

- Sidewalls covered with acoustical material Akustaplan (fig. 9); 
To all these, joins an electro-acoustics sound reinforcement system (SRS) with Bose loudspeakers and BSS processing. There are two columns with five loudspeakers, suspended at the center of the altar (fig. 10), responsible for the speech diffusion. At the altar right side six columns and four for low frequency, responsible for the organ amplification and also six wave cannons for extension of organ sound (fig. 11).
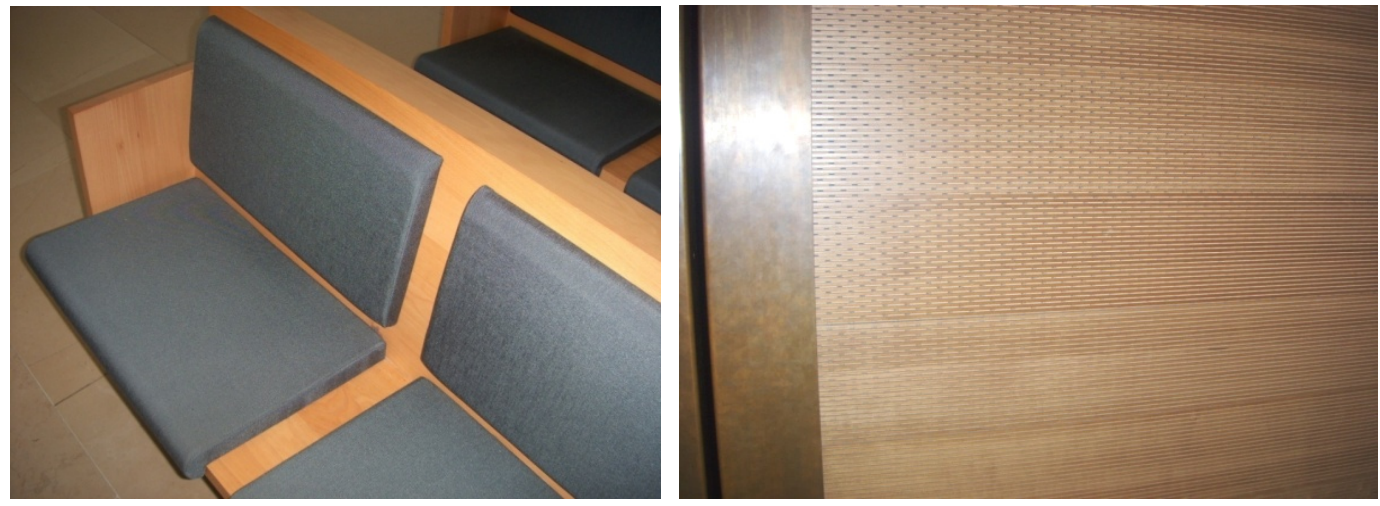

Figure 4 and 5 - Cushioned pews (left) and perforated panels (right).
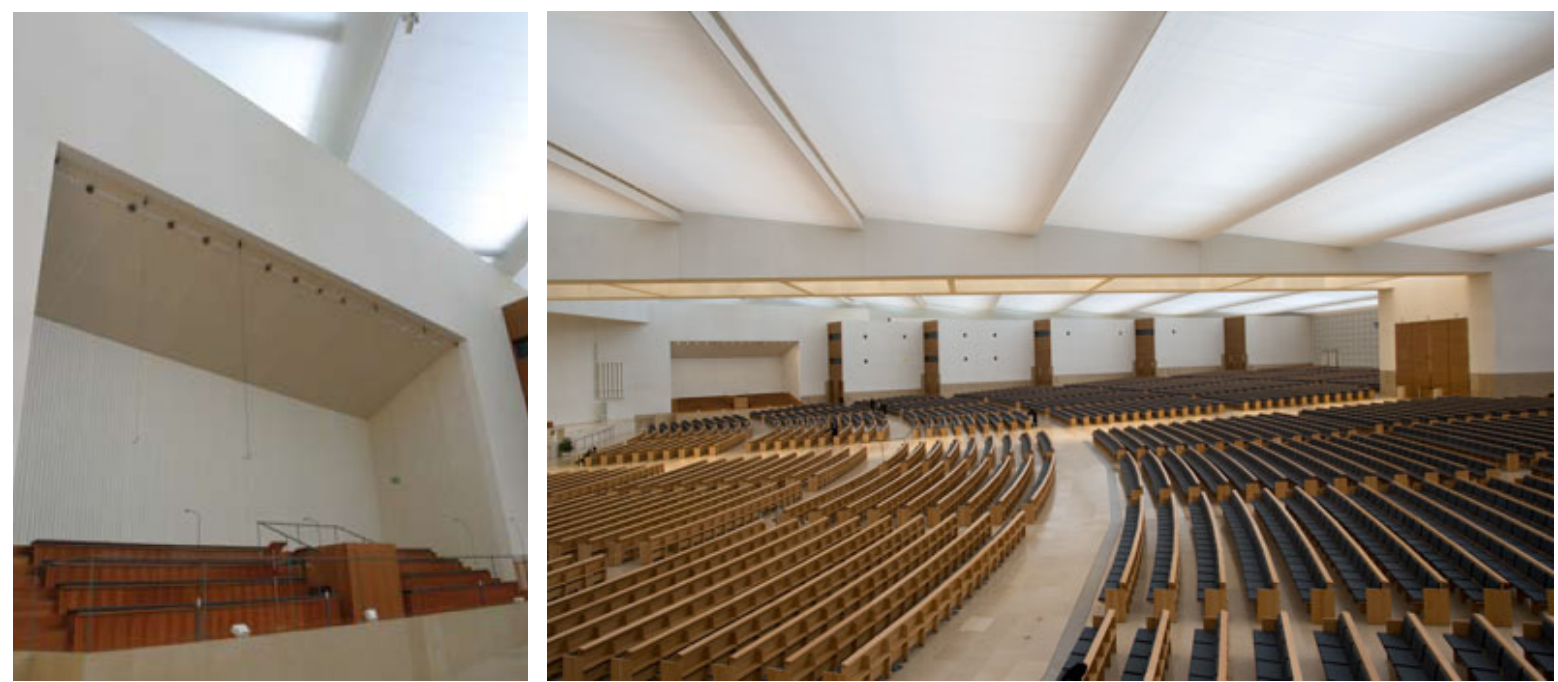

Figure 6 and 7 - Choir real wall (left) and church overview (right).
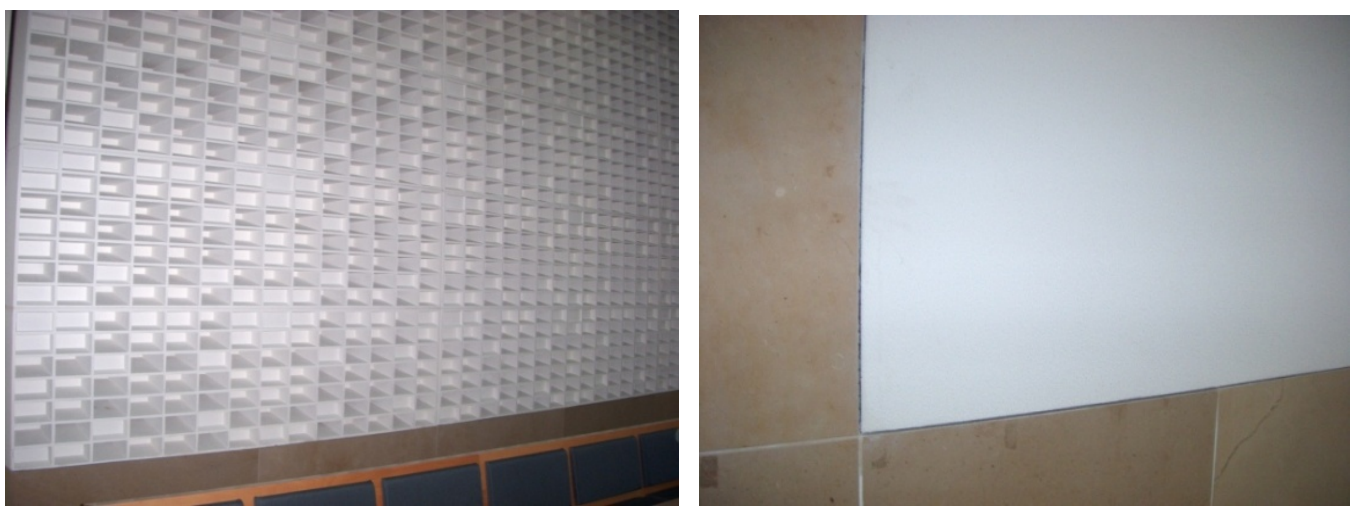

Figures 8 and 9 - Diffusers (on the congregation rear wall) (left) and wall with absorptive Akustaplan (white on photo at right). 

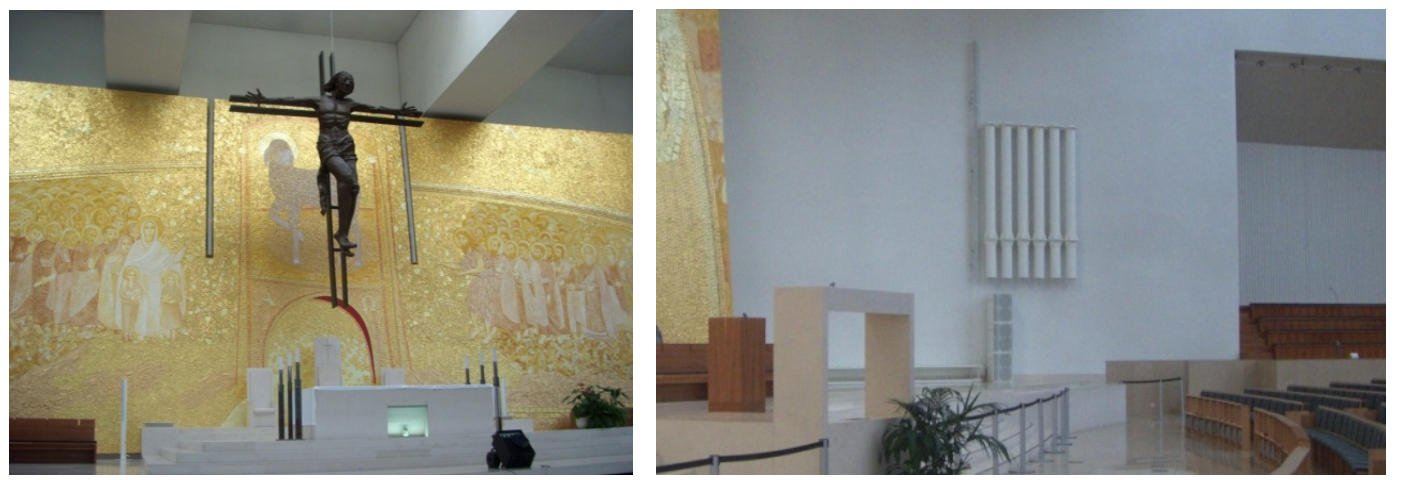

Figures 10 and 11 - Suspended loudspeakers (left) and loudspeakers and Wave Cannons for the organ (right).

\section{MEASUREMENTS}

Several parameters were measured in situ, on March 2009, at the unoccupied church:

- L (sound pressure levels) (and Noise Criteria NC) of the background noise with and without the HVAC equipment working (five measure points used);

- RASTI (Rapid Speech Transmission Index) noise with and without the use of the sound reinforcement system (eight measure points used, fig. 3);

- Reverberation Time (RT) by octave bands (125 to 4k Hz) (nine measure points used).

The equipment used was a B\&K sound level meter 2260 with a 1/2" microphone B\&K 4189, a sound source B\&K 4224 and the RASTI analyzer (B\&K 4225+4419).

\section{RESULTS AND DISCUSSION}

Background noise - The results regarding the sound pressure levels (L) for the background noise (with and without the HVAC system) are presented in Table 2. The HVAC system has a fairly low sound level (about $39 \mathrm{dBA}$ ) but it increases the initial low church background noise level between 13 and $19 \mathrm{~dB}(\mathrm{~A})$. All positions had $\mathrm{NC}$ values from 30 to 35 what show an increase of about $15 \mathrm{~dB}$ in the noise environment within the church.

Table 2 - Mean values of the sound pressure levels $(\mathrm{L})$ and sound levels $\left(\mathrm{L}_{\mathrm{A}}\right)$ of the background noise with and without the HVAC and the NC rating for each measuring position

\begin{tabular}{|c|c|c|c|c|c|c|c|c|c|}
\hline \multirow[b]{2}{*}{ Point } & \multicolumn{2}{|c|}{$\mathrm{L}(\mathrm{dB})$} & \multicolumn{2}{|c|}{$\mathrm{L}_{\mathrm{A}}(\mathrm{dB})$} & \multirow{2}{*}{$\begin{array}{l}\Delta \mathrm{L} \\
(\mathrm{dB})\end{array}$} & \multirow{2}{*}{$\begin{array}{l}\Delta \mathrm{L}_{\mathrm{A}} \\
(\mathrm{dB})\end{array}$} & \multicolumn{2}{|c|}{$\mathrm{NC}(\mathrm{dB})$} & \multirow{2}{*}{$\begin{array}{l}\Delta \mathrm{NC} \\
(\mathrm{dB})\end{array}$} \\
\hline & $\begin{array}{c}\text { with } \\
\text { HVAC }\end{array}$ & $\begin{array}{l}\text { without } \\
\text { HVAC }\end{array}$ & $\begin{array}{l}\text { with } \\
\text { HVAC }\end{array}$ & $\begin{array}{l}\text { without } \\
\text { HVAC }\end{array}$ & & & $\begin{array}{c}\text { with } \\
\text { HVAC }\end{array}$ & $\begin{array}{l}\text { without } \\
\text { HVAC }\end{array}$ & \\
\hline 1 & 51.5 & 35.0 & 38.3 & 24.2 & 16.5 & 14.1 & 32 & 18 & 14 \\
\hline 2 & 51.4 & 34.7 & 37.3 & 24.0 & 16.7 & 13.3 & 30 & 17 & 13 \\
\hline 3 & 52.2 & 34.4 & 38.0 & 23.8 & 17.8 & 14.2 & 31 & 18 & 13 \\
\hline 4 & 52.7 & 30.9 & 41.0 & 23.5 & 21.8 & 17.5 & 35 & 17 & 18 \\
\hline 5 & 52.8 & 30.6 & 40.6 & 21.7 & 22.2 & 18.9 & 35 & 16 & 19 \\
\hline Average & 52 & 33 & 39 & 23 & 19 & 16 & 33 & 17 & 15 \\
\hline
\end{tabular}


RASTI - The results regarding the RASTI (with and without the use of the church sound reinforcement system - SRS) are presented in Table 3 and Figure 12. On average the RASTI within the church is about 0.67 with the SRS on (an increase of 0.10 from the situation with the SRS off). These values show that the church has very good speech intelligibility and all the requirements set by the Owner are fulfilled.

Table 3 - RASTI values with and without the sound reinforcement system (SRS).

\begin{tabular}{|c|c|c|c|}
\hline Measuring points & SRS off & SRS on & $\triangle$ RASTI (on-off) \\
\hline 1 & 0.66 & 0.65 & -0.01 \\
\hline 2 & 0.61 & 0.62 & +0.01 \\
\hline 3 & 0.56 & 0.68 & +0.12 \\
\hline 4 & 0.53 & 0.70 & +0.07 \\
\hline 5 & 0.53 & 0.73 & +0.20 \\
\hline 6 & 0.59 & 0.64 & +0.05 \\
\hline 7 & 0.56 & 0.71 & +0.15 \\
\hline 8 & 0.51 & 0.66 & +0.15 \\
\hline RASTI avg & 0.57 & 0.67 & +0.10 \\
\hline
\end{tabular}

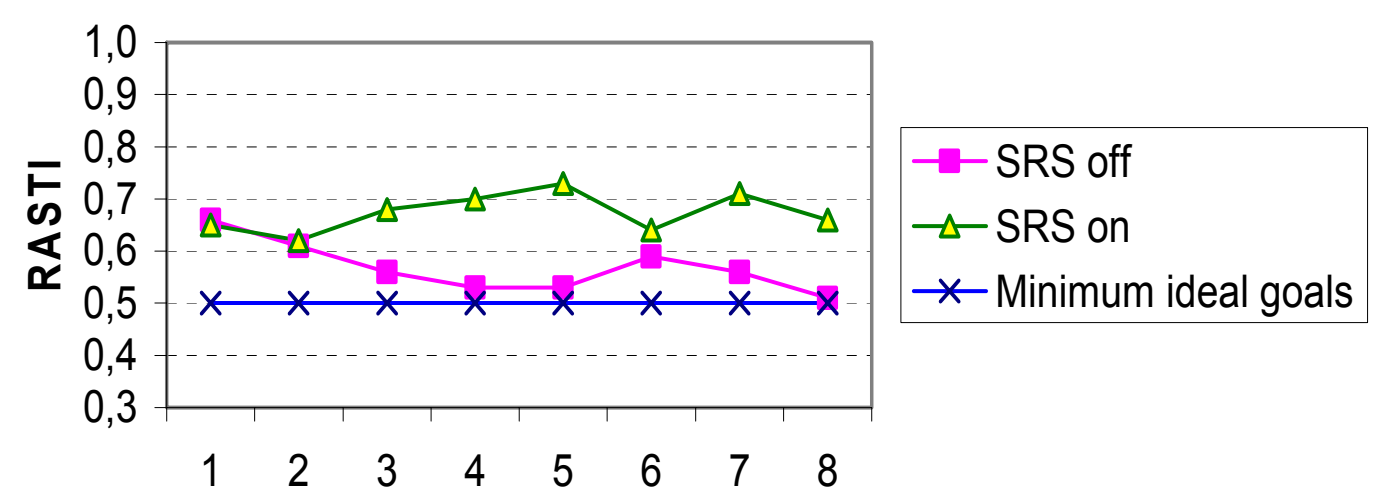

Measuring positions

Figure 12 - RASTI values within the church with and without the SRS compared with the minimum ideal goals.

Reverberation time - The results regarding RT are presented in Table 4 and Figure 13. The $500-1 \mathrm{k} \mathrm{Hz}$ RT values are between 1.7 and $2.5 \mathrm{~s}$ with an average of $2.1 \mathrm{~s}$. Those values fulfil the ideal goals in $2 / 3$ of the church and entirely for the acceptable limits. The $250 \mathrm{~Hz}$ RT values fulfil all the rules set.

Table 4 - Summary of RT values vs design RT goals.

\begin{tabular}{|l|c|c|c|c|}
\hline Parameter & $\begin{array}{c}\text { Measured values } \\
\text { within the church }\end{array}$ & $\begin{array}{c}\text { Average of } \\
\text { measured values }\end{array}$ & $\begin{array}{c}\text { Ideal project } \\
\text { goals* }\end{array}$ & $\begin{array}{c}\text { Acceptable } \\
\text { design limits* }\end{array}$ \\
\hline RT(500-1k Hz) (s) & 1.7 to 2.5 & 2.1 & $\leq 2.1$ & $\leq 2.6$ \\
\hline RT(250 Hz) (s) & 1.7 to 2.4 & 2.0 & $\leq 2.8$ & $\leq 3.4$ \\
\hline
\end{tabular}

* for every position within the church 


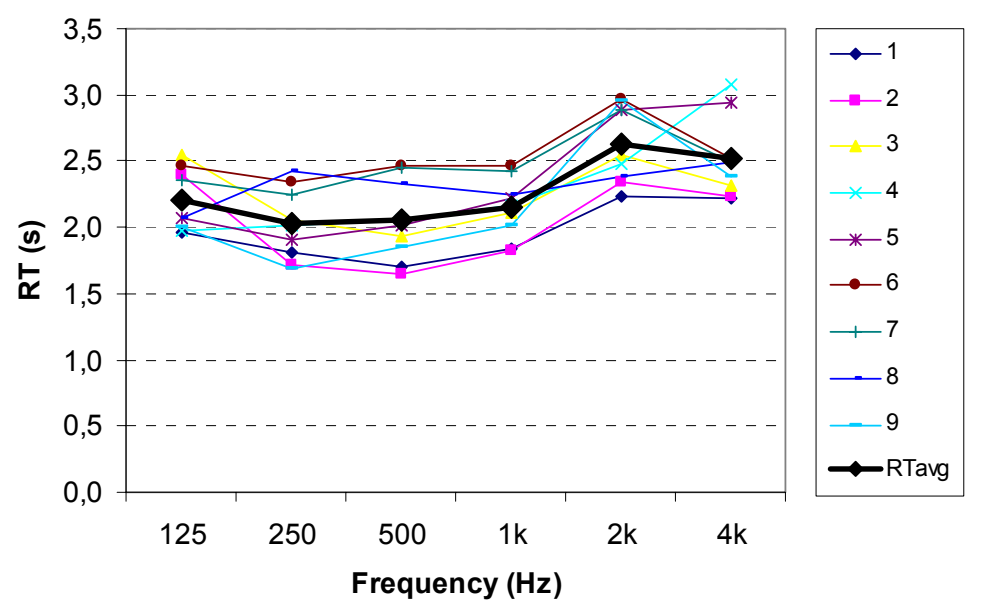

Figure 13 - Spectra of RT values in all the 9 measured points and the RTaverage

\section{INDEX METHOD OF THE ACOUSTIC QUALITY ASSESSMENT OF SACRAL BUILDINGS}

The Index Method of the Acoustic Quality Assessment of Sacral Buildings developed by Engel and Kosala [2] was tested in this church. It finds a global index $W_{A Q S}$ which is a function of partial indices as shown below:

$$
W_{A Q S}=\sum_{i=1}^{n} W_{i} \eta_{i} / \sum_{i=1}^{n} \eta_{i}
$$

where $W_{i}$ are five partial indices and $\eta_{\mathrm{i}}$ their weights $\left(\eta_{1}=1 ; \eta_{2}=0.5 ; \eta_{3}=0.3 ; \eta_{4}=0.3 ; \eta_{5}=\right.$ 0.2). These indices are: $W r$ (Reverberation index), Wis (Intelligibility of speech index), Wed (External disturbances index), Wul (Uniformity of loudness index) and Wm (Music sound quality index). All are rated in a scale 0 to 1.

The scale for the acoustic quality of a church according to the $W_{A Q S}$ is: $\operatorname{bad}\left(0 \leq W_{A Q S}<\right.$ $0.5)$; poor $\left(0.5 \leq W_{A Q S}<0.65\right)$; $\operatorname{good}\left(0.65 \leq W_{A Q S}<0.80\right)$ and very $\operatorname{good}\left(0.80 \leq W_{A Q S} \leq 1\right)$.

The $W r$ (Reverberation index) is found from: $W r=W r 1 . \beta 1+W r 2 . \beta 2+W r 3 . \beta 3$ where, Wr1 - reverberation-volume index, Wr2 - reverberation index for organ music and $\mathrm{Wr} 3$ - reverberation index for speaking.

$$
W r 1=1-\left(\left|R T_{Z S}-R T_{p}\right| / 5\right) \quad \mathrm{w}^{1-\frac{|T z s-T p|}{\mathbf{5}}} T p=0,24 \ln (V)-0,24=\text { here } R T p \text { is the }
$$

preferred RT for the church $(=0.24 * \ln$ (Volume)- 0.24 for Catholic churches, which gives, for the Holy Trinity church, $=2.6 \mathrm{~s}$ ) and RTzs is the measured RT corrected to the presence of people in the church. 
For the unoccupied church the measured RT is $2.1 \mathrm{~s}$. For the occupied church a RT (not measured) of 1.9 was chosen (RTzs).

According to the method [2], in this case RTzs is $1.9 \mathrm{~s}$ and the Holy Trinity church has a $\mathrm{Wr}_{1}$ of 1 .

$W r 2=1-\left(\left|R T_{Z S 500}-R T_{p O}\right| / 5\right)$ where $R T_{Z S 500}$ is the measured corrected RT for the 500 $\mathrm{Hz}\left(R T p o=0.73 \mathrm{~V}^{0.15}\right.$, for Holy Trinity church $\left.=4.3 \mathrm{~s}\right)$ and the RTpo is the preferred RT for organ music at $500 \mathrm{~Hz}$. For $R T z s_{500}$ it was used $1.9 \mathrm{~s}$, because the measured in the unoccupied church was $2.05 \mathrm{~s}$. Following the same approach as in the previous index, this $\mathrm{Wr}_{2}$ is also 1 .

$W r 3=1-\left(\left|R T_{Z S}-R T_{p M}\right| / 5\right)$ where $R T p M$ is the permissible $\mathrm{RT}$ for speech $(R T p M=$ $0.17 * \ln ($ Volume $)-0.43$, that gives for the Holy Trinity church $1.57 \mathrm{~s}$ ). Therefore, $W r 3=0.69$.

For this church it was used the $\beta 1, \beta 2$ e $\beta 3$ similar to those given in the method for churches about $40,000 \mathrm{~m}^{3}$ since this is the largest value available there. This does not guaranty the validity of this method for such a large church because it was developed for smaller churches (Holy Trinity church has more than three times that maximum volume). Nevertheless the following values were used: $\beta 1=0.6 ; \beta 2=0.3 ; \beta 3=0.1$. With those assumptions, $W r=0.97$.

The Wis (Intelligibility of speech index) is found from: $W i s=\left[\left(W_{s 1}{ }^{2}+W_{s 2}{ }^{2}+W_{s 3}{ }^{2}\right) / 3\right]^{1 / 2}$ Wis is supported by the parameters ALCons (Percentage Articulation Loss of Consonants) for $W i s_{1}, \mathrm{C}_{50}$ for $\mathrm{Wis}_{3}$ and RASTI for $\mathrm{Wis}_{2}$. The values chosen (using an educated guess) for Wis and $\mathrm{Wis}_{3}$ were the medium 0.5 because there was no measured data.

As the average measured RASTI was 0.57 , the $W i s_{2}=0.58$ (using figure in [2]). Therefore, $W i s=0.53$.

The Wed (External disturbances index) is found from Wed $=3 /\left(L_{A}-27\right)$ where $\mathrm{L}_{\mathrm{A}}$ is the noise level of external disturbances, inside the church. The value used ( $23 \mathrm{dBA})$ is the average of the background noise level without the use of the HVAC systems (table 2). Following the method's rules [2], $\mathrm{Wed}=1$.

$W m$ (Music sound quality index) is found from: $W m=\left[\left(W_{m 1}{ }^{2}+W_{m 2^{2}}{ }^{2}+W_{m 3}{ }^{2}+W_{m 4}{ }^{2}\right) / 4\right]^{1 / 2}$ $W m_{1}=0.63$ using the $\mathrm{RT}(500-1 \mathrm{k} \mathrm{Hz})=1.9 \mathrm{~s}$ and the suitable graph on [2]. $W m_{2}=0.46$ using the Bass Ratio calculated with a $\mathrm{RT}_{125}=2.0 \mathrm{~s}$ and $\mathrm{RT}_{250}=1.8 \mathrm{~s}$ and [2]. $W m_{3}=W m_{4}=1$ using the project average values $\left(\mathrm{C}_{80}=+2.5 \mathrm{~dB}\right.$ and Center Time $\left.=110 \mathrm{~ms}\right)$. Then, $\left.W m=\left(0.63^{2}+0.46^{2}+1^{2}+1^{2}\right) / 4\right]^{1 / 2}=0.81$.

For the Wul (Uniformity of loudness index) values were needed that were not available, like the sound pressure level decrease coefficient and the surface area on which the uniformity 
of loudness is investigated. Using an educated guess, a medium value of 0.5 was given to Wul.

Finally $\left.W_{A Q S}=0.97 * 1+0.53 * 0.5+1 * 0.3+0.5 * 0.3+0.81 * 0.2\right) /(1+0.5+0.3+0.3+0.2)=0.803$.

This value is at the borderline between the Good and Very Good interior acoustics classes. However, the exact number 0.803 is already in the Very Good class and a few options were done, in the method, that were very conservative (to give $W_{s} 1, W_{s} 3$ and $W u l$ a 0.5 ). If these were given 0.75 the $W_{A Q S}$ would be 0.87 , now clearly in the Very Good domain.

\section{COMPARISON OF HOLY TRINITY CHURCH WITH SIMILAR SIZE CHURCHES}

Table 5 and Figure 12 show twelve mega-churches in the world, their volumes and $\mathrm{RT}_{500-1 \mathrm{k}}$. Holy Trinity church (\#7) is one of the largest but has almost the lowest RT only surpassed by the Church of Jesus Christ of Latter-Day Saints (this, however, not a Catholic church) built in 2000. The two smallest average RT values are in churches built in the last decade what means that there seems to be now a concern about the interior acoustics.

Table 5 - Comparative analysis of mega-churches.

\begin{tabular}{|c|c|c|c|c|c|c|}
\hline$\#$ & Church & City & Country & People & $\begin{array}{c}\text { Volume } \\
\left(\mathrm{m}^{3}\right)\end{array}$ & $\begin{array}{c}\text { RT(500-1k Hz) } \\
(\mathrm{s})\end{array}$ \\
\hline 1 & St. Peter & Rome & Vatican & 58,000 & 700,000 & 7.0 \\
\hline 2 & $\begin{array}{c}\text { Church of Jesus Christ of } \\
\text { Latter-Day Saints (200) }\end{array}$ & $\begin{array}{c}\text { Salt Lake } \\
\text { City }\end{array}$ & USA & 21,000 & 226,000 & 2.0 \\
\hline 3 & St. Paul Outs. the Walls & Rome & Italy & 38,000 & 181,000 & 8.6 \\
\hline 4 & St. Paul's Cathedral & London & UK & 31,000 & 152,000 & 10.7 \\
\hline 5 & S. John in Luterano & Roma & Italy & 23,000 & 150,000 & 6.2 \\
\hline 6 & Klosterkirche & Ottobeuren & Germany & $n a$ & 130,000 & 6.5 \\
\hline 7 & Holy Trinity (2007) & Fátima & Portugal & 9,000 & 130,000 & 2.1 \\
\hline 8 & First Baptist Ch. (1985) & Orlando & USA & 6,000 & 115,000 & 2.9 \\
\hline 9 & Monastery S.to Domingo & Silos & Spain & $n a$ & 113,000 & 6.5 \\
\hline 10 & Marien Church & Lübeck & Germany & $n a$ & 100,000 & 5.5 \\
\hline 11 & $\begin{array}{c}\text { St. Mary's Church } \\
(\text { Bazylika Mariacka })\end{array}$ & Gdańsk & Poland & 25,000 & 97,000 & 11.4 \\
\hline 12 & Klosterkirche & Weingarten & Germany & $n a$ & 90,000 & 7.2 \\
\hline
\end{tabular}

na- not available 


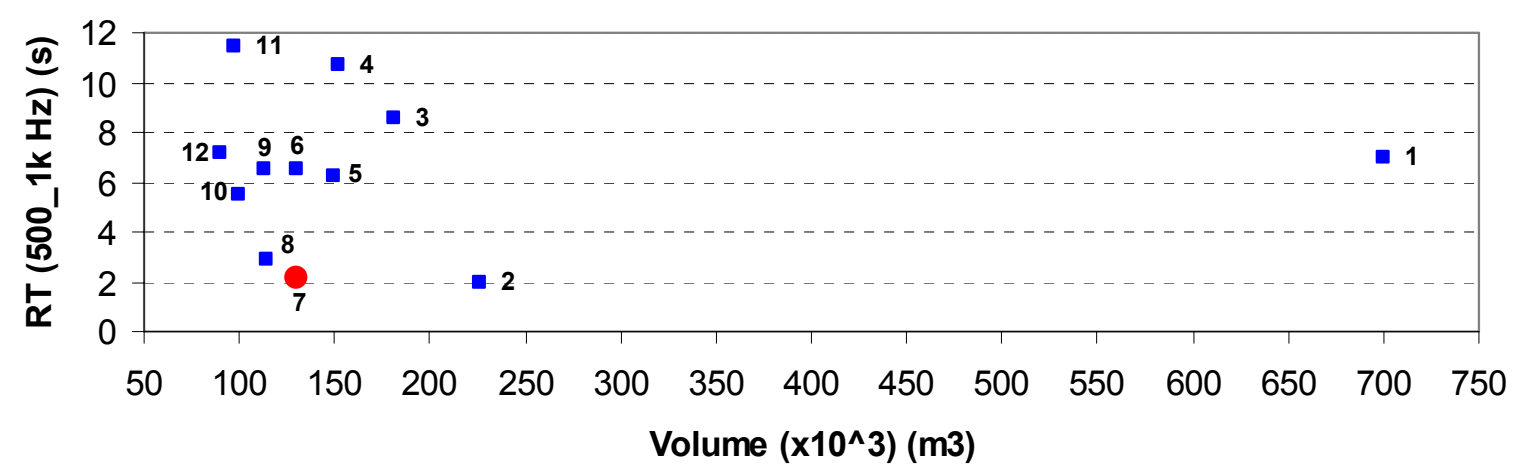

Figure 12 - Average RT (500-1k Hz) for twelve mega-churches (Fátima Holy Trinity: red dot).

\section{CONCLUSIONS}

Table 6 presents the summary of the measured values. The $N C$ values were between 30 and $35 \mathrm{~dB}$, above the acceptable limit of $30 \mathrm{~dB}$. However these values may be caused only by a few badly connected ventilators' grilles that make an unusual noise (rumble). The HVAC makes the background noise level to increase about $16 \mathrm{~dB}(\mathrm{~A})$ reaching a value of about 39 $\mathrm{dB}(\mathrm{A})$ that it is not unreasonable.

Table 6 - Summary of measured values and comparison with the Owner previously set goals.

\begin{tabular}{|l|c|c|c|c|c|c|}
\hline \multirow{2}{*}{ Parameters } & Measured & Avg. meas. & Project Requirements & \multicolumn{2}{c|}{ Result } \\
\cline { 5 - 7 } & values & values & Ideal & Acceptable & Ideal & Acceptable \\
\hline NC (dB) & 30 to 35 & 33 & $\leq 25$ & $\leq 30$ & $\mathrm{ko}^{3}$ & $\mathrm{OK}^{2,3}$ \\
\hline RASTI with SRS & 0.62 to 0.73 & 0.67 & $\geq 0.50$ & $\geq 0.45$ & $\mathrm{OK}$ & $\mathrm{OK}$ \\
\hline RT (500-1k Hz) (s) & 1.7 to 2.5 & 2.1 & $\leq 2.1$ & $\leq 2.6$ & $\mathrm{OK}^{1}$ & $\mathrm{OK}$ \\
\hline RT $(250 \mathrm{~Hz}) \quad$ (s) & 1.7 to 2.4 & 2.0 & $\leq 2.8$ & $\leq 3.4$ & $\mathrm{OK}$ & $\mathrm{OK}$ \\
\hline
\end{tabular}

${ }^{1}$ only in $67 \%$ of the church; ${ }^{2}$ only in $20 \%$ of the church ${ }^{3}$ pending work in the grilles

The RASTI values show that all the requirements are largely meet and they reflect the good work in trying to achieve excellent speech intelligibility within the entire space.

The $\mathrm{RT}_{500 \_1 \mathrm{k}}$ values show that the acceptable limits are fulfilled in all points. However, $33 \%$ of the positions exceed the exigent ideal goal. For the $\mathrm{RT}_{250}$ all the positions presented values below the ideal goal. It can be concluded that the materials and systems used were capable to transform a very difficult shape and size into a very good space for a church and for its speech intelligibility and religious music.

In general all the exigent requirements set by the owner were met except the NC values (but in this case a simple fix of the grilles will transform the situation). 
Using the Engel and Kosala's Index Method this church achieved a rating of Very Good that is in accordance with the previously stated.

Among the largest Christian churches, Holy Trinity stands out as one with the best acoustics for speech and music.

The main conclusion is that a strong and accurate acoustic project that involves Owner, architect and acoustical consultant will give incredibly good results.

\section{REFERENCES}

1 A. Carvalho and D. Freitas, The new megachurch for the Sanctuary of Fátima, $10^{\text {th }}$ ICSV Int. Cong. on Sound and Vibration, Stockholm, Sweden, 2003.

2 Z. Engel and K. Kosala, Index method of the acoustic quality assessment of sacral buildings, Archives of Acoustics, 32(3), 3-22, 2007. 